\title{
Analisis Wacana Resistensi Hak Kekayaan Intelektual (HKI) Sebagai Budaya Global Oleh Pelaku Seni Indonesia Khususnya Di Bali
}

\author{
I Nyoman Lodra \\ Pendidikan Seni Rupa, Fakultas Bahasa dan Seni, Universitas Negeri Surabaya, 60213, Indonesia. \\ n.lodra@yahoo.co.id
}

Penelitian ini bertujuan untuk mengetahui resistensi terhadap budaya global seperti HKI oleh pelaku seni Indonesia, khususnya di Bali. Sebagai negara berkembang Indonesia telah mengadaftasi budaya tersebut ke dalam Undang-Undang HKI. Implementasikan di pasar global Indonesia, khususnya di daerah Bali, masih terjadi resistensi oleh pelaku seni tradisional yang kerapkali abaikan, apriori terhadap HKI. Fokus permasalahan: (1) bagaimana bentuk resistensi terhadap HKI di Bali? (2) apa faktor-faktor penyebab resistensi HKI di Bali? (3) bagaimana dampak resistensi terhadap HKI di Bali?. Tujuan, (1) mendiskripsikan bentuk resistensi HKI di Bali (2) mengetahui faktor penyebab resistensi HKI di Bali (3) mengetahui dampak resistensi terhadap HKI di Bali. Manfaat; hasil penelitian: mencarikan solusi untuk mengatasi resistensi HKI di Bali. Metode penelitian deskriptif kualitatif, dengan pendekatan yuridis emperis. Pengumpulan data primer dan sekender, dengan pengambilan data: observasi, wawancara, dan dokumen. Analisis digunakan teori wacana, teori praktik sosial, dan teori dekonstruksi. Sumber data, manusia, jurnal, buku, validitas dengan trianggulasi data, trianggulasi sumber. Hasil: ditemukan resistensi terhadap HKI oleh pelaku seni di Bali yang disebabkan oleh faktor internal dan eksternal.

Kata kunci: wacana, resistensi, budaya global, pelaku seni.

\section{Discourse Analysis Of Intellectual Property Rights (Ipr) Resistance As A Global Culture By Indonesian Artist Especially In Bali}

This research aimed to determine resistance to global culture such as IPR by Indonesian artist, especially in Bali. As a developing country it has adapted that culture into the IPR Constitution Law. Implemented in the Indonesian global market, especially in the Bali region, there is still resistance by traditional art actors who often ignore, a priori against IPR. The focus of the problem: (1) what was the resistance form to IPR in Bali? (2) what were the factors causing IPR resistance in Bali? (3) what was the resistance impact to IPR in Bali?. Objectives, (1) described IPR resistance form in Bali (2) found out the factors that cause IPR resistance in Bali (3) determined the resistance impact to IPR in Bali. The benefits; research results: found solutions to overcome IPR resistance in Bali. This research used descriptive qualitative with an empirical juridical approach. Primary and secondary data collection used: observation, interviews, and documents. The analysis used discourse theory, social practice theory, and deconstruction theory. Data sources, humans, journals, books, validity with data triangulation, source triangulation. Results: found resistance to IPR by artist in Bali caused by internal and external factors.

Keywords: discourse, resistence, global culture, artist

Proses Review : 18 - 31 Agustus 2020, Dinyatakan Lolos: 7 September 2020 


\section{PENDAHULUAN}

Hak Kekayaan Intelektual atau disingkat HKI adalah hak didapat oleh individu atau sekelompok orang yang telah menghasilkan sesuatu ciptaan, hasil rekayasa berupa produk atas dasar kemampuan olah rasa, olah pikir, berguna untuk kehidupan manusia. Penemu (inventor) HKI dalam bidang teknologi, ilmu pengetahuan, seni, desain, dan rancangan lain bersifat kebaharuan (novelty) memiliki nilai moral, ekonomis, dan sosial. Menelusuri dan menganalisis tekstual, dan inplementasinya diketahui prinsip-prinsip HKI lebih mengedepankan nilai ekonomis ketimbang nilai moral dan sosial. Konsep, gagasan pemikiran tersebut merupakan pola kelompok pengusaha, pedagang dari negara-negara maju. HKI oleh negara maju tersebut seperti menjadikan sebuah ideologi yang diterapkan dalam pasar intenasional untuk menekan negara-negara berkembang. Beberapa negara berkembang seperti Indonesia, setelah di implementasi HKI masih menjadi pro-kontra, terutaman di daerah-daerah berbasis budaya tradisional. Ideologi dimaksudkan adalah suatu ide, gagasan untuk membuat suatu perubahan dengan proses pemikiran normatif dengan kepentingan publik di samping memiliki kepentingan politik. Menurut Alfian ideologi adalah sebuah pandangan, sistem nilai sifatnya menyeluruh dan mendalam dalam kepentingan moral dianggap benar dan adil dalam mengatur tingkah laku kehidupan. (https://www.maxmanroe. com/vid/umum/pengertian-ideologi.html).

HKI sebagai budaya dari negara-negara maju menjadi sebuah kekuatan mengatur dan menekan negara berkembang yang ikut dalam perdagangan internasional atau global. Lembaga yang mewadahi perdagangan internasional membidangi HKI adalah World Intelectual Property Organization (WIPO) khusus dibentuk oleh Perserikatan Bangsa-Bangsa (PBB), dimana Indonesia termasuk dalam organisasi dunia tersebut. Dengan begitu secara langsung Indonesia ikut dan masuk dalam sistem perdagangan global yang diatur oleh WIPO. Pada posisi ini HKI memiliki arti penting dan nilai ekonomis sebagai persyaratan mutlak kepada siapapun yang ikut dalam perdagagan global. Sistem perdagangan global dengan segala peraturan, termasuk persyaratan penyertaan sertifikat HKI (Sardjono, 2006: 3). Oleh Smiers, persyaratan yang digariskan oleh lembaga tersebut di atas lebih mencerminkan ideologi libralis, kapitalis dari negara-negara maju dan sebagai kekuatan perangkat kontrol hukum bagi setiap kreasi artistik (2009: 92). Oleh Marx, perdagangan global merupakan ruang bagi kelompok libralis, kapitalis menyebarkan ideologi yang lebih mengedepankan konsep individual, kelompok, ekonomis, serta petimbangan mencari keuntungan sebanyak-banyaknya (dalam Barker, 2006: 14).

Indonesia termasuk negara berkembang sebagai anggota WIPO, telah meratifikasi dan mengadofsi budaya global tersebut kedalam undang-undang HKI. Implementasi atau penerapan HKI di Indonesia terjadi "kegaduhan" atau risestensi dari pelaku seni tradisional.Hal tersebut terjadi karena masing-masing daerah di Indonesia memiliki karakteristik budaya berbeda-beda yang tidak sesuai dengan prinsip-prinsip HKI. Seperti halnya karakteristik budaya daerah Bali, pelaku seni tradisional dalam penciptaan bersifat kolektif, kebersamaan, gotongroyong, sosial religius, dan "yadnya". Karakteristik budaya daerah tersebut bertentangan dengan prinsip HKI yang lebih mengedepankan individualistik, kelompok, dan ekonomis. Maka begitu di implementasikan undang-undang HKI terjadi "kegaduhan", kepanikan, dan risestensi (perlawanan) oleh pelaku seni tradisional. Mereka memahami dan mengerti setelah karya ciptaan dilindungi HKI, ciptaan tersebut tidak bebas lagi untuk ditiru, dijiplak tanpa seijin pemilik dan dikatagorikan sebagai plagiasi yang bisa dikenakan sanksi pidana dan perdata. Sedangkan pekerja seni tradisional di Bali memiliki sifat meniru, kolektif, gotongroyong, dan anonim serta berlandaskan pada nilainilai agama Hindu. Sebagai penguatan ada beberapa hasil penelitian sebelum yang relevan seperti berikut.

Sigit Nugroho, 2015, Perlindungan Hak Kekayaan Intelektual Dalam upaya Pembangunan Ekonomi di Era Pasar Bebas Asean, Fakultas Hukum Universitas Bangka Belitung. Dalam penelitian tersebut pada intinya mempersoalankan bangsa Indonesia dalam menghadapai pasar bepasar bebas. Salahsatu penyiapan para pelaku-pelaku lokal mempersiapkan pembangunan Hak Kekayaan Intelektual yang dibutuhkan di pasar bebas ASEAN. HKI merupakan aset terpenting dalam membangun perekonomian bangsa berbasis ilmu pengetahuan, namun dalam pelaksanaan di Indonesia banyak mengalami hambatan karena adanya perbedaan karakteristik masyarakat lokal dengan prinsip pasar bebas. Untuk itu di indonesia perlu adanya pembenahan pembangunan sistem HKI sesuai dengan budaya bangsa.https://ejournal.unib.ac.id/index. php/supremasihukum/article/viewFile/1199/1004

Emma Valentina, 2015, Efektivitas Pengaturan Hukum Hak Cipta Dalam melindungi Karya Seni Tradisional, kajian bahasan pemahaman dan ketrampilan masyarakat dalam pengembangan ekonomi terkait dengan keefektipan pengaturan hukum Hak Cipta dalam melindungi karya tradisional daerah. Dalam kajian karya seni tradisional dengan Undang-Undang Nomor 28 tahun 2014 tentang Hak Cipta ditemukan kelemahan dan kelebihan yang diharapkan menjadi bahan kajian untuk perbaikan dalam pengaturan perundangan-undangan dimasyarakat.https:// ejournal.unsrat.ac.id/index.php/lppmekososbudkum/article/viewFile/10661/10249

Sulasi Rongiyati, 2016, Hak Kekayaan Intelektual atas Pengetahuan Tradisional mengkaji persoalan perlunya ada pengakuan dan perlindungan hukum yang mampu menjaga memelihara dan mengembangkan sumber daya alam, seni, dan budaya sebagai pengetahuan tradisional yang dimiliki oleh negara berkembang seperti Indonesia. 
Namun pada kenyataan dalam implementasinya oleh negara -negara maju belum mengakuinya secara maksimal, hal ini disebabkan karakteristik budaya tradisional bersifat komunal, terbuka dan minim pemahaman terhadap sistem HKI.https://jurnal.dpr.go.id/index.php/hukum/article/ view/214

Muhamad Arif, Rosni, 2018, Pemanfaatan dan Pengelolaan Hak Atas kekayaan Intelektual (HKI) Sebagai Strategi Pengembangan Kewirausahaan, Pendidikan Geografi fakultas Ilmu Sosial Universitas Negeri Medan, dengan fokus kajian kekayaan intelektual yang dimiliki oleh setiap dosen merupakan aset bernilai ekonomis dan bermanfaat untuk pengembangan nasional dan daerah.Seperti hasil penenelitian, temuan, rekayasa dan pengabdian masyarakat harus diimplementasikan dengan terlebih dahulu dilindungi dengan HKI, dengan tujuan agar tidak terjadi konflik kepemilikan karya ciptaan dikemudian hari.https:// jurnal.unimed.ac.id/2012/index.php/geo/article/viewFile/8632/7573

Nahrowi, Plagiat dan Pembajakan Karya Cipta Dalam Hak Kekayaan Intelektual, fokus pembahasan undang-undang Hak cipta untuk perlindungan kekayaan seni dan pengembangan kemampuan intelektual masyarakat Indonesia untuk membangun usaha yang dibutuhkan dalam pembangunan nasional. Disisi lain pekerja seni, pengusaha masih marak terjadi pembajakan atau plagiat pada karya cipta di Indonesia bahkan dibelahan negara maju..http://journal. uinjkt.ac.id/index.php/salam/article/view/1541

Mira Burri, 2019, Cultural Heritage ang Intellectual Property, University of Lucerne, Forthcoming in the Oxford Handbook of International Cultural Heritage Law, (Oxford University Press,) .Penelitian tersebut di atas secara khusus membahas masalah institusi hukum terkait dengan perlindungan kekayaan intelektual dan hubungan dengan warisan budaya khususnya takbenda. Pembahasan lebih lanjut dengan mengekplorasi seberapa jauh kekayaan intelektual melindungi ekspresi warisan budaya seperti paten, hak cipta atau merk dagang.

Lee Branstetter, 2017, Intellectual Property Rights, Innovation and Development:Is Asia Defferet?, Penelitian terkait dengan para pembuat kebijakkan ekonomi di negara-negara berkembang telah menolak tekanan untuk memperkuat sistem hak kekayaan intelektual (IPR) mereka. Tidak sedikit dari mereka menunjukan keberhasilan industri teknologi tinggi di Asia sebagai konfirmasi dalam menjaga sistem HKI yang dapat berfungsi sebagai kebijakan industri, merangsang pertumbuhan perusahaan-perusahaan pribumi yang dinamis secara teknologi. https://doi. org/10.1177/0976399616686860

Kajian penelitian tersebut di atas menggambarkan bahwa negara Indonesia telah mengadaftasi, meratifikasi HKI ke dalam Undang-Undang dan tampak ada respon dari kelom- pok pengusaha ataupun di kalangan akademis. Pengimplementasan Undang-Undang tersebut ke masyarakat oleh pelaku seni tradisional masih banyak mengalami hambatan dalam bentuk resistensi. Pada sisi lain HKI menjamin kesejahteraan kreator melalui perjanjian kontrak atau lisensi. Untuk mengetahui kenapa terjadi resistensi oleh pelaku seni tersebut, perlu dilakukan penelitian mendalam dengan tema: ANALISIS WACANA RESISTENSI HAK KEKAYAAN INTELEKTUAL (HKI) SEBAGAI BUDAYA GLOBAL OLEH PELAKU SENI INDONESIA KHUSUSNYA DI BALI. Penelitian ini penting dilakukan agar diketahui secara pasti akar penyebab resistensi dan mencarikan solusi agar pelaku seni tradisional di Bali tidak terjebak pada pemahaman yang keliru.

\section{METODE}

Metode penelitian deskriptif kualitatif dengan pendekatan yuridis emperis terkait dengan pelaksanaan HKI, khususnya di daerah Bali. dengan ketidakterbatasan waktu. Sumber data dari hasil observasi ke beberapa kelompok pengusaha perak, sanggar tari, wawancara dengan pelaku seni tradisional, kajian beberapa jurnal nasional, internasional, buku, dan kajian dokumen sertifikat HKI dengan pembedahan teori analisis wacana, pratik sosial.

\section{HASIL PEMBAHASAN}

\section{Resistensi HKI}

Tertulis dalam undang-undang HKI yang berhak mendapatkan mendapatkan perlindungan (proteksi) adalah karya ciptaan, rekayasa bidang seni, desain, sastra, dan teknologi dari individu ataupun kelompok. Pada prinsip HKI dalam perwujudan menggunakan kemampuan intelektual (akal, rasio) manusia. Undang-undang tersebut menyebutkan sebagai hak alamiah dengan demikian semua orang menghormati dan menghargai. Menurut Sudaryat, Dkk (2010:15) HKI sebagai hak atau suatu benda ciptaan atas kerja otak dan nalar dalam perwujudan benda-benda yang bisa diraba, disentuh dan tidak terwujud (immaterial), seperti alunan lagu, puisi, panton, dan karya sastra dan materisl seperti disain, kerajinan, seni lukis, patung, dan karya seni rupa lainnya. Lebih lanjut Peters dan Koesriani KI yang mendapatkan hak perlindungan melalui penciptaan dengan kemampuan intelektual manusia. Selaras dengan pemikiran Edi Sedyawati (2008:1) HKI sebagai pengetahuan hasil dari pemikiran dan aktivitas manusia dalam kaitan kebudayaan yang telah digunakan dari generasi ke generasi dalam suatu komunitas. Lebih luas pandangan dari lembaga WIPO yang dimaksud sebagai pengetahuan tradisional yakni mencakup indigenous, knowledge, and folklor bersifat immaterial.

Dalam masyarakat ada sistem kepercayaan dimiliki oleh kelompok masyarakat bersifat kolektif, merupakan bentuk kekhasan dari budaya tradisional (Sardjono,2006:19). KI tradisi yang berkembang di Bali tersebut kemudian 
diproteksi dengan HKI, dengan kepemilikkan individu, kelompok mendapat penolakan atau risistensi. Oleh pelaku seni tradisional, HKI hanya ditelaah dari sudut pandang yang sempit tidak mencermati ciptaan yang bisa mendapatkan proteksi ciptaan yang memiliki nilai kebaharuan. Khusus proses penciptaan karya seni pada produk ada nilai kebaharuan (novelty).

Pada perkembangan pengetahuan, teknologi, perdagangan global oleh kelompok negara maju yang bersifat libralis dan kapitalis menjadikan peluang bisnis yang menguntungkan. Oleh negara maju semua KI di proteksi dengan HKI. Kemajuan pengetahuan, teknologi digital negara maju dalam posisi lebih diuntungkan mereka dengan mudah bisa menguasai KI ciptaan siapa saja termasuk seni tradisional yang sebelum sempat di proteksi. Seperti halnya indikasi nilai-nilai budaya tradisional Bali diproteksi oleh warga negara lain (Fajar Bali,29 April 2008). Dengan demikian agar tidak terjadi klaim-mengklaim dasar kesadaran moral dan kebutuhan ekonomis semua jenis KI yang diciptakan membutuhkan perlindungan atau proteksi HKI. Untuk semua itu dibutuhkan kesadaran dari pekerja seni, industri untuk memproteksi KI oleh karena selain nilai moral juga bernilai ekonomis. KI yang sudah diproteksi HKI bernilai ekonomis bagi individu atau orang lain dengan cara memperbanyak atau memproduksi untuk kepentingan bisnis dengan ikatan perjanjian kontrak atau lisensi. Keterbatasan pada pemahaman HKI oleh pelaku seni tradisional nilai-nilai warisan budaya leluhur dianggap tidak sebagai KI, maka begitu implementasi mendapatkan reaksi penolakan atau risistensi. Bentuk risistensi seperti sikap apriori, enggan untuk mendaftarkan semua ciptaan yang bersumber dari budaya tradisi.

\section{HKI Idiologi Negara Maju}

Negara maju adalah sebuah negara dimana masyarakatnya hidup dengan standart relatif tinggi termasuk bidang teknologi, perdagangan, dan ekonomi yang merata. Dengan kemajuan-kemajuan yang dimiliki tersebut kecendrungan dari mereka memiliki idiologi lebralis dengan penonjolan yang bersifat individu dan kapitalis lebih mengedepankan ide untuk mendapatkan keutungan bagi individu (Althusser, Louis. 2008). Negara tersebut memiliki kondisi lebih baik disegala bidang ketimbang dengan negara berkembang ataupun negara tertinggal. Dalam kegiatan kelompok negara maju seperti ide membentuk lembaga World Intellectual Property Organisation (WIPO), dalam pratik perdagangan global. Pada perdagangan global juga mewadahi negara-negara berkembang ataupun negara tetinggal, dengan kondisi budaya yang berbasis sosial religius. Pada umumnya negara berkembang dilandasi budaya bersumberkan pada tradisi-tradisi yang berkembang dilingkungan masyarakat bersifat magis, religius, sosial, dan gotongroyong. Sedangkan HKI dikenal sebagai budaya dari negara-negara maju beratarbelakang libralis dan kapitalis yang lebih mempertimbangan keuntungan individu, kelompok. Kelompok negara maju memiliki kekua- saan (fower) ide, gagasan untuk menerapkan penyertaan HKI dalam lembaga World Trade Organisation (WTO). Negara-negara berkembang termasuk Indonesia ada dalam wadah tersebut tampak belum maksimal bisa untuk menyiapkan persyaratan tersebut. Dalam hal ini kelompok negara berkembang ataupun tertinggal yang ada dalam wadah perdagangan dunia tersebut mau tidak mau harus mengikuti persyaratan tersebut. Pada posisi tidak bisa menolak dan ada pada posisi termajinalkan atau tidak dominan. Hal tersebut Eriyanto, menyebut dalam kontek teks analisis wacana menunjukan kelompok mayoritas akan unggul dengan kelompok minoritas (2009:18). Memaknai pemikiran Eriyanto tersebut pelaku sini tradisional ada pada posisi termajirnalkan dalam konteks global.

Gambaran kondisi perdagangan global yang dimotori oleh lembaga World Trade Organisation (WTO), oleh negara berkembang menjadi persoalan yang disebabkan oleh perbedaan idiologi dan karakteristik budaya. Di sisi lain penerapan persyaratan HKI dalam perdagangan global tersebut terkesan adanya kekuasaan yang dipertontonkan dari kelompok negara maju yang membuat ketidakberdayaan kelompok negara berkembang. Hal tersebut oleh peneliti disebut sebagai bentuk representasi sebuah pertarungan idiologi dari kelompok negara maju dengan kelompok negara berkembang di ranah global.

\section{Wacana "Pertarungan" Idiologi}

Analisis wacana memungkinkan untuk bisa melihat ada dan tidaknya motivasi yang tersumbunyi di balik sebuah tekstual terkait dengan pernyertaan HKI pada pasar global. Hal tersebut sebagai sebuah pemaksaan sehingga terjadi pemaknaan sebuah "pertarungan" idiologi dari negara maju dengan negara berkembang. Pasar global atau trans internasional yang di gawangi oleh lembaga World Trade Organisation (WTO) sebuah lembaga yang mengatur perdagangan dunia dengan penyertaan sertifikat HKI (Sardjono, 2006: 3). Untuk bisa masuk pasar global dengan penyertaan persyaratan tersebut menjadi momok atau kendala pelaku bisnis dari negara-negara berkembang seperti Indonesia khususnya oleh pelaku seni tradisional di Bali. Konsep besar pekerja seni tradisional Bali berlandaskan pada kepentingan bersama, gotongroyong, "yadnya", anonim berbeda dengan hakekat HKI adalah individu, kelompok, dan ekonomis. Penyertaan HKI dalam pasar global telah diundangkan oleh setiap negara yang menjadi anggota WTO, termasuk Indonesia yang telah diundangkan dalam undang-undang HKI. HKI dalam bidang Hak Cipta diatur dengan Undang-Undang Nomor 28 tahun 2014, terkait dengan perlindungan Hak Cipta. (https://m. hukumonline.com/pusatdata/detail/1t5460681737444/undang-undang-nomor-28-tahun-2014).

Dalam analisis wacana tekstual dari implementasi HKI oleh negara berkembang sebagai pesan-pesan dari bentuk pradigma berpikir dimaknai sebagai sebuah "pertarungan" idiologi atau kekuasaan negara maju berhadapan-hadapan dengan negara berkembang. Secara tekstual terjadi bentuk 
dominasi, hegomoni terhadap kelompok-kelompok termajinalkan. Sejalan dengan Foucault wacana sebagai pratik sosial yang berperan sebagai pengontrol, menormalkan, dan mendisiplinkan individu (Eriyanto: 2009:hal 19-19). Hal tersebut lebih mencerminkan ideologi kapitalis dari bentuk sikap, filosofi negara-negara maju dan sebagai kekuatan perangkat kontrol hukum bagi setiap kreasi artistik (Smiers, 2009: 92). HKI pada prinsipnya adalah hak untuk menikmati hasil kreativitas manusia dalam bentuk KI (Sudaryat Dkk, 2010:15).

Implementasi penerapan dan pelaksanaan HKI di Indonesia khususnya di daerah Bali, menjadi sebuah dilema oleh karena konsep kehidupan masyarakatnya lebih mengedepankan kebersamaan, kolektif, dan sosial religius. Perhatikan metode pengajaran seni tari, tabuh, seni lukis tradisi seperti gaya lukis Batuan, Kamasan, Ubud di Bali di awali dengan meniru (menjiplak). Pelatih, pengajar, guru merasa bangga jika anak asuh, didik mereka bisa meniru dengan persis apa yang mereka ajarkan. Sifat-sifat berbeda dengan dan kecedrungan kontraproduktif dengan idiologi HKI itu sendiri. Idiologi pekerja seni tradisional di Bali tersebut juga dilandasi memberi kesempatan orang untuk meniru di pahami sebagai bentuk "yadnya" dan diyakini membawa kebaikan bagi semua orang. Hal tersebut menjadi sebuah persoalan bagi pemerintah dalam penerapan undang-undang HKI di masyarakat. Konsep penciptaan pelaku seni di Bali bertolakbelakang dengan prinsip-prinsip HKI dimaknai sebagai sebuah wacana "pertarungan" idiologi di ranah pasar global sudah pasti akan di akhiri dengan kekalahan di pihak pekerja seni tradisional, hal itu disebabkan HKI sudah di undangkan.

\section{Faktor Penyebab Resistensi HKI.}

Undang-Undang HKI sudah sejak lama diimplementasikan di seluruh daerah Indonesia, termasuk Bali. Dalam pelaksanaan di lapangan tidak semulus yang dibayangkan oleh para pemangku kebijakan. HKI merupakan hasil adofsi budaya dari negara-negara maju memiiki filosofi lebralis dan kapitalis berbeda jauh dengan prinsip kerja pelaku seni tradisional. Pelaku seni tradisional di Bali bekerja dengan landasan sosial spritual, bersama, ekonomi dengan nilai-nilai "yadnya". Implementasi undang-uandang tersebut di masyarakat Bali menjadi sebuah "delima", melaksanakan HKI bertentangan dengan prinsip "yadnya", jika tidak melaksanakan ada semacam acaman dan ketakutan. Jika dikaji secara mendalam HKI memberi motivasi menumbuhkan kreativitas pelaku seni dan dapat memberi kesejahteraan bersifat berkelanjutan atau permanen melalui "lisensi". Tampaknya oleh pekerja seni di Bali masih sulit diterima oleh karena pijakan budaya berlandaskan pada nilai-nilai agam Hindu yang mengedepankan pada kolektivitas, menjaga kelestarian ysng semusnys diyakini sebagai bentuk yadnya. Hal tersebut oleh O'Dea, sebagai masyarakat yang menganut konsep ritual (dalam Sumandiyo, 2006: 31).
Resistensi merupakan suatu manifestasi dari bentuk perlawanan dengan cara menunjukan sikap apriori, enggan dengan maksud menolak ideologi asing karenabertentangan dengan konsep, filosofi kehidupan masyarakat di Bali. HKI bentuk sebagai kekuatan asing yang dilawan oleh pelaku seni tradisional di Bali dengan sikap apriori (cuek), dan tidak mengindahkan dimaknai sebagai bentuk penolakan. Alasan penolakan, objek kreasi kreatif pelaku seni di Bali bersumber dari warisan budaya dan sudah ada sejak zaman dahulu yang perlu dilestarikan dan dikembangkan, sehingga siapa pun boleh memakainya. Di sisi lain kulture pekerja seni tradisional Bali, merasa bangga karyanya ditiru oleh orang lain. Sikap-sikap tersebut jelasnya berdampak pada pembatasan ruang intraksi pasar lokal saja. Hal ini juga berdampak pada sulitnya pelaku seni Bali masuk di pasar global. Pada kesempatan lain para penggiat seni asing di Bali, dengan mudahnya melakukan proteksi dengan perlindungan HKI, hal tersebut berpotensi munculkan "kegaduhan". .

Temuan dari hasil penelitian Lodra (Desetasi: 2011) beberapa faktor penyebab apriori, ketidakpedulian, keengganan dari pelaku seni di Bali pada implementasi HKI adalah sebagai berikut.

\section{Faktor Internal}

\section{a.Kurang Pemahan Tentang HKI}

Konsep kreasi kreatif penciptaan oleh pelaku seni tradisional di Bali, seperti karya tari, lukis, patung, kerajinan perak bersumber pada nilai-nilai budaya yang telah diwariskan oleh para leluhur (habitus). Pemahaman masyarakat budaya warisan tersebut bisa dimanfaat bersama namun tidak elok diklaim menjadi milik individu ataupun kelompok. Tampak masyarakat khusus para pelaku pekerja seni tradisi di Bali belum paham dengan bentuk objek yang bisa dan tidak dilindungi atau diproteksi dengan HKI. Warisan budaya sering dijadikan objek kreasi kreatif termasuk cagar budaya tidak bisa dilindungi dengan HKI. Hasil kreasi ciptaan bersumber budaya tradisi dengan nilai kebaharuan baru dapat dilindungi dengan HKI.

\section{b.Sistem Kekrabatan}

Sikap keengganan, apriori pekerja seni tradisi di Bali untuk melindungi hasil ciptaannya karena kulture masyarakat yang dijiwai agama Hindu, kehidupan sosial di atur dalam "awig-awig" yang merujuk pada konsep tri hita karana. Maka kekerabatan masyarakat yang menjunjung tinggi nilai kebersamaan, kolektivitas, gotong royong, "yadnya" membuat mereka enggan karya-karya ciptaan mereka untuk dilindungi HKI.

\section{c.Lemah Motivasi}

Pekerja seni tradisional kebanyakan memiliki talenta dalam pembuatan produk seperti terampil dalam penguasaan desain, teknik, dan finishing namun sangat lemah dalam pembuatan narasi konsep karya. Kelemahan tersebut menyebabkan lemahnya motivasi pelaku seni tradision- 
al untuk mengurus pendaftaran HKI pada produk ciptaan mereka.

\section{Faktor Eksternal a.Kurang Sosialisasi}

Ketidak tahuan pelaku seni tradisi di Bali tetang bagaimana cara pelindungan, apa yang perlu disiapkan, apa kegunaan, dan dampak jika karya-karya ciptaan tidak dilindungi itu perlu disosilisasikan. Menurut pengakuan dari pelaku seni dan juga mengkompermasikan ke lembaga terkait sosialisasi HKI memang sangat terbatas belum maksimal. Semestinya sebelum Undang-Undang HKI diterapkan terlebih dahulu lembaga terkait mensosialisasikan ke masyarakat pelaku seni di Bali.

\section{b. Pelayanan Pendaftaran}

Pada tahun 1988, ketika terjadi komplik HKI di Bali, pelayanan pendaftaran relatif masih sangat kurang, informasi masih sangat minim, tempat pendaftaran dilayani di beberapa tempat seperti di kantor Disperindag Kabupaten dan di Kakanwil Hukum dan Ham Propinsi, dan lembaga swasta lainnya. Pada saat ini telah banyak dilakukan pembenahan-pembenahan untuk pendaftaran HKI dan dilakukan diregulasi dengan penyederhanaan adminstrasi, tempat pendaftaran, dan percepat masa tunggu. Seperti halnya HKI bidang Hak Cipta, telah di buka pendaftaran melalui online. Adanya deregulasi pendaftaran HKI bidang Hak Cipta direspon baik oleh lembaga-lembaga perguruan tinggi, tetapi pekerja seni tradisi masih belum ada yang memanfaatkan kemudahan tersebut.

\section{c.Administrasi Pendaftaran}

Keengganan, apriori pelaku seni pada perlindungan HKI di Bali disebabkan rumitnya mekanisme dan persyaratan pendaftaran. Hal tersebut sampai di lembaga terkait untuk administrasi pendaftaran di sederhanakan. Pemerintah terus mendorong pelaku seni (kelompok bisnis, seniman, pengerajin, desainer, dan kelompok profesi lain) untuk mendaftarkan dan melindungi produk-produk mereka dengan HKI. Tujuannya agar produk ciptaan, rekayasa dikemudian hari tidak menjadi persoalan hukum. Deregulasi pada sektor perlindungan dilakukan dengan penyederhanaan kelengkapan adminitrasi pendaftaran. Dengan kemudahan-kemudahan mekanisme dan persyaratan pendaftaran pelaku seni tradisional belum banyak juga berbuat untuk melindungi hasil ciptaan mereka.

\section{c.Biaya Pendaftaran}

Sebelumnya tahun 2018 tersebut terjadi komplik HKI antara pelaku seni tradisi dengan pelaku seni asing di Bali pada waktu itu tempat pendaftaran hanya di Dinas Perdagangan dan Perindustrian, Kanwil Hukum dan Ham, dan lembaga swasta terkait biaya pendaftaran relatif mahal. Pengakuan dari beberapa pengerajin perak di Desa Celuk Sukawati Gianyar seperti: Desak Nyoman Suarti (60 tahun), Wijaya (60 tahun), Romo (55 tahun) mengaku selain kesulitan melengkapi administrasi, juga biaya pendaftaran relatif masih mahal. Setelah ada deregulasi pendaftaran HKI seperti saat sekarang biaya pendaftaran HKI bidang Hak Cipta relatif bisa dijangkau, tetapi pekerja seni tradisional masih belum banyak yang merespon. Pola berpikir pelaku seni tradisional di Bali masih pragmatis, mereka menghitung biaya dikeluarkan untuk megurus hak cipta dengan harga jual produk. Kebayakan mereka berpikir dengan hitungan setiap produk yang laku dijual dikakulasi dengan perhitungan proses produk dan pembelian bahan. Deregulasi pendaftaran HKI tersebut banyak dimanfaatkan oleh kalangan akademisi, pengusaha, dan perguruan tinggi di Bali.

Faktor-faktor penyebab apriori, keengganan pelaku seni tradisional untuk pendaftaran HKI dimaknai sebagai bentuk risistensi atau perlawanan pada persyaratan perdagangan global. Sikap tersebut merugikan pelaku seni lokal yang menyebabkan "ketumpulan" kreativitas, kawatir tuduhan sebagai plagiasi, dan bebas pelaku seni asing memanfaatkan nilai budaya tradisional. Implikasi dari dampak yang timbul akibat sikap apriori, keengganan dalam pengurusan HKI terus akan muncul komplik berkepanjangan diantara pelaku seni lokal, dan dengan pengusaha asing. Jika hal ini terus dibiarkan tidak tertutup kemungkinan terjadi terpasung kreatifitas pelaku seni tradisional, disharmonisasi hubungan kekrabatan, munculnya kolonialisasi budaya

\section{DISKUSI}

Pekerja seni dari negara maju lebih rasional dalam manfaat perlindungan HKI terkait dengan deregulasi pasar global. Perlindungan pada setiap produk merupakan peluang besar untuk bisa masuk pasar global dan merupakan modal penting dalam memenangkan persaingan. Mereka bisa membaca keunggulan dan nilai pasar dari sebuah produk, maka mau membelanjakan uangnya untuk membeli produk orang lain tanpa susah-susah melakukan proses penciptaan. Dengan modal uang mereka bisa membeli sekaligus melindungi produk yang mereka telah kuasai. Sepeti pengalaman desainner X i (60 tahun) dari Ubud Bali, bercerita tentang pengalaman buruknya. Pada tahun 1996 dia menjual kerajinan perak dengan motif desain "kelabang"(anyaman dari daun kelapa), dan motif "kelakat" (sebitan bambu yang di anyam) kepada orang asing. Kedua desain motif tersebut belum di lindungi HKI di beli oleh orang asing. Kedua desain motif tersebut memiliki nilai jual tinggi dan belum diproteksi HKI, kemudian pembeli memproteksi atas nama sendiri. Ketika desainer $\mathrm{X}$ menjual produk dengan desain yang sama, muncul komplik hukum karena ada indikasi plagiasi. (wawancara tgl 5 desember 2008 dengan desainer X). Pada tahun 2008 terjadi hal yang sama menimpa pelaku seni desainer XX, (50 tahun) yang dituduhkan ada indikasi melakukan plagiasi desain milik pengusaha asing (Fajar Bali, 29/4/2008).

Kajian dari pengalaman-pengalaman dari komplik dua desainer lokal dengan pengusaha asing tersebut menan- 
dakan ada klaim kepemilikan. Menghidari terjadi klaimmengklaim kepemilikan sebaiknya pelaku seni lokal dan pengusaha asing pada setiap produk karya desainnya terlebih dahulu di lindungi dengan HKI sebelum dijual. Para desainer juga perlu hati-hati tidak semua nilai-nilai budaya bisa dilindungi HKI. Seperti halnya, UU Hak Cipta. pasal 10 ayat (1) dan (2) berbunyi sebagai berikut.

“Ayat (1) Negara memegang hak cipta atas karya peninggalan prsejarah, sejarah dan benda nasional lainnya,ayat (2) Negara memegang hak cipta atas foklor dan hasil kerajinan rakyat menjadi milik bersama termasuk karya seni kerajinan (Sinar garfika,2008:6). Dengan memperhatikan ketentuan undang-undang HKI, dan pasal, dan ayat-ayat tersebut di atas persoalan komplik kepemilikan tidak akan terjadi, kreativitas tumbuh dengan "subur", kesejahteraan masyarakat tercapai.

\section{SIMPULAN}

Hasil pembahasan terkait dengan analisis wacana Hak Kekayaan Intelektual atau disebut HKI sebagai budaya global, dimana implementasinya oleh pelaku seni di Indonesia khusunya di Bali dapat disimpulkan seperti berikut.

1. Bentuk resistensi pelaku seni tradisional di Bali terhadap HKI, seperti kulture pelaku seni tradisional Bali, merujuk pada nilai-nilai ajaran agama Hindu, dalam konsep "Tri Hitekarana" munumbuhkan budaya gotongroyong, kolektivitas, dan kebersamaan sangat bertolak belakang dengan konsep HKI.

2. Faktor-faktor penyebab resisitensi pelaku seni tradisional di Bali terhadap HKI seperti berikut.

Faktor Internal

a. Kurang pemahaman tentang pengetahuan HKI, sistem kekrabatan masyarakat di Bali masih menjunjung tinggi kebersamaan, gotogroyong, dan adanya pemahaman tentang "Yadnya".

b. Motivasi untuk mendaftarakan karya-karya ciptaan mereka karena mereka kurang memperhatikan dalam konsep berkarya sehingga untuk narasi karya diabaikan.

Faktor Ekternal

a. Kurang adanya sosilaisasi kepada masyarakat khususnya pelaku seni tradisional di Bali

b. Tempat pelayanan pendaftaran masih jauh dari lingkungan, administrasi masih dianggap nyelimet, dan biaya masih dianggap memberatkan pelaku seni tradisional di Bali.

3. Dampak resistensi terhadapa HKI, sulitnya masuk pasar global, memberi peluang pelaku usaha asing untuk mengklaim budaya lokal, mandegnya kreatifitas, dan tidak bisa tercapainya kesejahteraan pelaku seni tradisional serta berpotensi munculkan komplik dengan pengusaha lokal ataupun asing di Bali. Begitu juga terpasungnya kreativitas dan produktivitas pelaku seni tradisional karena dibayang-banyangi ketidaktahuan mereka apakah ciptaan mereka terma- suk plagiasi atau sudah dilindungi HKI oleh orang lain.

\section{DAFTAR RUJUKAN}

Abdulah, Irwan. (2007), .Konstruksi dan Reproduksi, Yogyakarta: Pustaka Pelajar.

Agger, Ben. (2007), Teori Sosial Kritis, Penerapan dan Implementasinya (terjemahan), Yogyakarta: Kreasi Wacana.

Althusser, Louis. (2008), Tentang Ideologi. Yogyakarta: Jalasutra.

Armstrong, Karen. (2007), The Great Transformation. Bandung: Mizan.

Anonim. (2008), Undang-Undang HAKI Hak Atas Kekayaan Intelektual. Jakarta: Sinar Grafika.

Ardana, Gede, I Gusti. (2007), Pemberdayaan Kearipan Lokal Masyarakat Bali dalam Menghadapai Budaya Global.denpasar Tarukan Agung.

Barker,Cris. (2008), Culture Studies. Yogyakata:Kreasi Wacana.

Capra, Frijof. (2008), Titik Balik Peradaban. Yogyakarta:Benteng.

Damaian, Eddy. (2002), Hukum Hak Cipta. Bandung: PT Alumni.

Denzin, Norman K. Lincoln, Ynvonnas. (2009), Handbook Of Qualitative research. Yogyakarta: Pustaka Pelajar.

Dormer, Peter. (2008), Makna Modern. Yogyakarta@ Bandung :Jalasutra.

Eriyanto. (2009), Analisis Wacana Pengatar Analisis Media. Yogyakarta:LKiS

Fashri, Fausi. (2007), Penyikapan Kuasa Simbol. Yogyakarta:Yuxtapose.

Kaplan, David. Allbert A. Manner. (1999), Teori Budaya, Yogyakarta: Pustaka Pelajar

Laeyendecker. (1991), Tata Perubahan dan Ketimpangan, Jakarta:Garmedia Pustaka Utama.

Lodra, I Nyoman. (2002), Kerajinan Perak Suarti Sebagai Karya Tandingan di Pasar Global (tesis) Program Pascasarjana Universitas Udayana Denpasar. 
Massudilawe \& Partners. (2008), Himpunan Undang-Undang Hak Kekayaan Intelektual.Yogyakarta: CV Andi Offset.

Norris. Christoper. (2008), Membongkar Teori Dekonstruksi Jacques Derrida. Ar-Ruzz. Yogyakarta: Media Group.

Putra,Wiyasa.IB.(1998), Bali Dalam Perspektif Global. Denpasar Upade Sastra.

Riswandi, Agus, Budi. (2005), Hak Kekayaan Intelektual dan Budaya Hukum.Jakarta:PT.Raja Grafindo Persada.

Samekto,Adji,Fx. (2005), Kapitalis Modernisasi dan Kerusakan Lingkungan.Yogyakarta: Pustaka Pelajar.

Sardjono, Agus, (2006), Hak Kekayaan Intlektual dan Pengetahuan Tradiional. Bandung: PT Alumni Bandung.

Saidin. (1995), Aspek Hukum Hak Kekayaan Intlektual. Jakarta: PT RajagrafindoPersada.

Sukeni.Ni Nyoman. (2002), Konflik Perupa di Bali dan Pengendaliannya (tesis) S2 Program Pascasarjana Universitas Udayana. Denpasar.

Takwin, Bagus. (2003), Akar-Akar Idiologi. Yogyakarta: Jalasutra.

Titib, I Made. (2003), Teologi dan Simbol-Simbol dalam Agama Hindu.Surabya: Pramita.

Triguna,Yudha IBG. (2008), Kebudayaan dan Modal Budaya Dalam Teropong Lokal,Nasional, Global.Denpasar:Widya Dharma.

Sedyawati,Edi (2008), Pengetahuan Tradisional sebagai Kekayaan Intelektual:Tinjauan atas Penggunaannya Dalam Industry Budaya.Naskah lengkap Seminar Nasional,Nusa Dua Bali.4 Desember.

Sudaryat, Dkk. (2010), Hak Kekayaan Intelektual. Bandung: Oase Media.

Widja, I Gusti Nyoman. (2008), Upaya Perlindungan Pengetahuan Tradisional dan Eksprisi Budaya Tradisional. Naskah Lengkap Seminar Nasional. Nusa Dua Bali 4 Desember.

Mira Burri, (2019), Cultural Heritage ang Intellectual Property, University of Lucerne, Forthcoming in the Oxford Handbook of International Cultural Heritage Law, (Oxford University Press,)

FK Philips, (2016), Intellectual Property Rights In Traditional Knowledge: Enambler of Sustainable Develop-
ment,Utrecht Journal Of Internatioal and European Law.

Niken Prasetyawati. (Juni 2014), "PERLINDUNGAN HAK CIPTA DALAM TRANSAKSI DAGANG INTERNASIONAL", Jurnal Sosial Humaniora, Vol 4 No.1.

Media HKI.Vol.V/N0.2. (2008), Perlindungan Hak Cipta di Era Digital Ditinjau dari Sudut Ligitasi.

Media HKI. (2007), "Penegakan Hukum di Bidang Hak Kekyaaan Intelektual, Derektorat Jendral Hak Kekayaan Intelektual". Departemen Hukum dan Hak Asasi Manusia Republik Indonesia, Hal 11.

Fajar Bali, (29 April 2008), "Kantongi Sertifikat Hak Cipta, Malah Didakwa Melanggar” Fajar Bali.

Radar Bali, (8 Agustus 2006), "Penggunaan dan Peringatan Hak Cipta dan Desain Industri” Radar Bali.

Global Justice Update. (4 Februari 2020), Negara-Negara Berkembang Suarakan Keprihatinan terhadap Perundingan WTO, Global, http:/www.igj.or.id

"Perlindungan Pengetahuan Tradisional di Indonesiia Perlu Aturan Tegas", www.ugm.ac.id

Maxmanroe. (4 Februari 2020), Pengertian Ideologi: Arti, Fungsi, dan Jenis-Jenis Ideologi https://www.maxmanroe. com/vid/umum/pengertian-ideologi.html

Fathan Qorib. (4 Februari 2020), Undang-Undang Nomor 28 Tahun 2014 https://m.hukumonline.com /pusatdata/ detail/lt5460681737444/undang-undang-nomor- 28-tahun-2014

Nahrowi. (4 Februari 2020), Plagiat Dan Pembajakan Karya Cipta Dalam Hak Kekayaan Intelektual http://journal.uinjkt.ac.id/index.php/ salam /article/ view/ 1541

Muhammad Arif, Rosni. (4 Februari 2020), Pemanfaatan Dan Pengelolaan Hak Atas Kekayaan Intelektual (HKI) Sebagai Strategi Pengembangan Kewirausahaan https:// jurnal.unimed.ac.id/2012/index.php/geo /article/ viewFile $18632 / 7573$

Lee Branstetter. (4 Februari 2020), Intellectual Property Rights, Innovation and Development: Is Asia Different? https://doi.org/10.1177/0976399616 686860

Sulasi Rongiyati. (4 Februari 2020), Hak Kekayaan Intelektual atas Pengetahuan Tradisional https://jurnal. dpr. go.id/index.php/hukum/article/view/214

Sigit Nugroho. (4 Februari 2020), Perlindungan Hak Kekayaan Intelektual Dalam Upaya Peningkatan Pembangunan Ekonomi Di Era Pasar Bebas Asean https:// ejournal.unib.ac.id/index. php/ supremasihukum /article/ 
viewFile/1199/1004 